\title{
モーションキャプチャデータの削減手法による 特徴キーフレームの自動抽出とその応用
}

近藤 邦雄, 岡崎真知子, 土井章男, 松田 浩一

埼玉大学工学部情報システム工学科, 岩手県立大学ソフトウェア情報学部

要旨：モーションキャプデー夕は、人の動きをそのまま測定するため、リアルな動作データが得られる が、冗長な情報を含んでいる場合が多く、動作の修正や变更には多くの手間と時間が掛かる。本研究では、 測定した動きの特徴をそのまま生かし、圥長な情報を削減する手法を提案し、モーションキャプチャデー 夕をユーザーにとって扱い易いものとすることを目的とする。そこで、モーションデータの xyz 軸の角度 データに対し制御点削減を行なう手法を提案する。この手法を用いて削減したモーションキャプチャデータ の動作の比較や検討をしたした結果、提案手法を用いて削減されたモーションキャプチャデータは削減前と 比較するとほほ同等の動きをすることが確認された。また、特徵となる動きのみを抽出するため、動作強調 法に対し有効であることが確認できた。この削減手法の特徵は以下の通りである。（1）測定した動きの特 徵を生かした削減が可能である。（2）削減の割合をユーザがコントロールできる。（3）デー夕量の削減が 実現できるので大量の動きのデータベース構築に有効である。(4) デー夕量を削減することによって、動 きの修正が容易に行なうことができる。（5）削減したデー夕は動作強調法に対し有効である。提案手法に より、元の動きの特徵を保持しながらデー夕量は約 50 \%に抑えることが可能となった。

キーワード：CG、コンピュータアニメーション、キーフレーム削減、動作データベース

\section{1 はじめに}

コンピュータの高性能化により、現在コンピュー タグラフィックスは様々な分野で注目され、利用され ている。コンピュータを用いることにより様々なも のを映像化することができ、また制作作業の省力化 が可能等の利点があるためである。

特にエンターテイメントの分野においては 3 次元 化された背景やキャラクタを利用したコンピュータ グラフィックスが多用されるようになってきた。そ の動作生成手法についてはさまざまな研究が行われ ており、計算による動作を撮影した映像から解析す る手法、物理法則や運動学、逆運動学を用いた手法、 実測值をそのまま利用するモーションキャプチャシ ステムを利用した手法などが挙げられる。モーショ ンキャプチャシステムによる動作デー夕は実際の動 作から得られた情報を利用するため、リアルな動作 データが得られる。しかし、モーションキャプチャ システムによる動作データは動きごとにデータを取

336-8570

埼玉県浦和市下大久保 255
らねばならず、また、動作デー夕の修正や変更には 多くの時間と経験を必要とする。また、これらの手 法から望みの動作を生成するには、多くのパラメー 夕を操作したり、何度も作り直すというような多く の手間と時間が必要である。そこで最近では、基本 的な動作を望みの動作に自動的に変換する研究が行 なわれている [3][4]。本論文では、モーションキャプ チャシステムから得られたデー夕のて長な情報を削 減し、特徵となるキーフレームを抽出する手法を提 案する。提案手法により、元の動きを保持しながら デー夕量は、元の 50 \%に抑えることが可能となり、 制御点を削減することでユーザにとって扱いやすい データとなった。

\section{2 提案手法の概要}

コンピュータアニメーションにおける動きの生成 は、計算による自動生成やモーションキャプチャシ ステムによる乎法が多く研究されている。 モーションキャプチャシステムによる動作データ 
は動きごとにデータを取らねばならず、誤差を含む 場合もあり、望みの動作を得る為の動作データの修 正や変更には多くの時間と経験を必要とする。

そこで、本研究では、モーションキャプチャシス テムで得られた動作データから誤差と思われる点を 削除し、特徴となるキーフレームのみを抽出する手 法を提案する。

モーションキャプチャシステムから得られた動作 データのxyz 軸に関する回転角度デー夕に対し、筆 者らの曲線清書手法を用いてモーションキャプチャ データの制御点削減を行なう。

また、削減したモーションデータを使用し筆者ら の提案した動作強調法 [8] を用い、動作強調を行なっ た。制御点削除を行なうことにより、以下のことが 可能である。

1. データの少量化により、効率的に大規模デー夕 ベースが構築可能

2. 動作の特徵を生かした、動きのスムージングが 可能

3.デー夕量が減ることにより、デー夕制御が容易 になる

4. 動作強調に対し有効なデータとなり、3 次元 $\mathrm{CG}$ アニメーションの操作生成手法として利用できる

\section{3 モーションデータ削減手法}

本節では、制御点削除の手法として、筆者らの提 案した手描き曲線の清書手法である、節点分割抽出 法を改良した手法を用いている。この清書手法では、 手描きによる手振れや歪みとなる部分を取り除き、清 書曲線の制御点を得ることができる。節点分割抽出 法では比を用いた制御点選択法を用いているため、大 きな動きの部分には大まかな制御点選択を行い、細 かな動きの部分には細かな制御点選択を行えるとい う特長がある。そこで本研究では、この手法を改良 し、三軸のモーションデータへの適用を可能にした。 本節では、まず接点分割抽出法の概要について述べ、 次にモーションデー夕削減用への改良手法について 述べる。

\section{1 モーションデータ削減手法概要}

まず、基本となる節点抽出法アルゴリズムを示し、 次に節点分割抽出法のアルゴリズムを述べる。
節点抽出法のアルゴリズムを次に示す。

1. 折れ線の端点 $P_{0}, P_{1}$ を結ぶ

2. 線分 $P_{0}, P_{1}$ から最も遠い点 $P$ を選ぶ

3. 端点間の距離 $l$ と直線 $P_{0} P_{1}$ からの $\mathrm{P}$ の距離 $h$ の比を求め、閾值 $\varepsilon$ 未満の場合は、その区間の 処理は終了

4. 閾値 $\varepsilon$ 以上の場合は $\mathrm{P}$ を節点として選択し、 $P_{0} P, P_{1} P$ の区間において同様に再帰的に区間 分割を行なう。

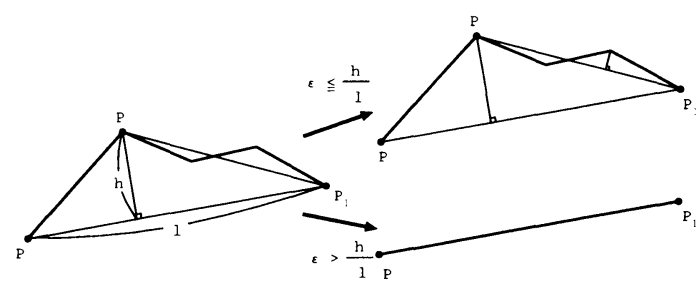

図 1: 節点抽出法

この節点抽出法を曲線用に改良した手法が筆者ら の提案した節点分割抽出法である。節点抽出法を行 なう前にあらかじめある程度の区間分割を行ない、形 状特徽をできるだけ残すようにしている。図 2(1) で は、端点 $P_{0} P_{1}$ を結ぶ直線と入力曲線との交点を区 間分割点 $P$ とし、さらに、分割した部分の端点と極 大・極小值を結ぶ直線を作り、交点 $C$ を持つ場合は $\left(P P_{1}\right)$ 、その点において区間分割を行なう (図 2(2))。 交点を持たない区間 $\left(P_{0} P, C P, P P_{0}\right)$ では、節点抽出 法により制御点の削減を行なう。

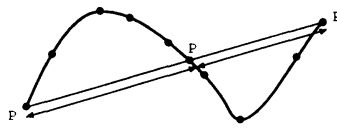

（1）交差判定による区間分割

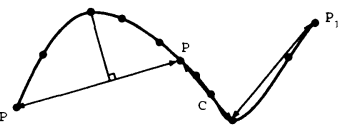

（2）㮔大・糧小点による区間分割
図 2: 節点分割抽出法

\section{2 直線・曲線のセグメンテーション}

モーションキャプチャした角度データでは、部位 によっては動きがない時間があり、その部分は角度 データグラフには水平な直線として現れる。前節に 
おいて述べた接点分割抽出法は曲線清書手法である ため、角度変化のない部分すなわち水平部分への対 応ができない。そこで水平部分を検出し、直線部分 と曲線部分に分割する。

本論文では、直線の幅を全体の振幅の $1 / 100$ 未満 とし、その幅の中にある点を連続した点として検出 する（図 3 )。

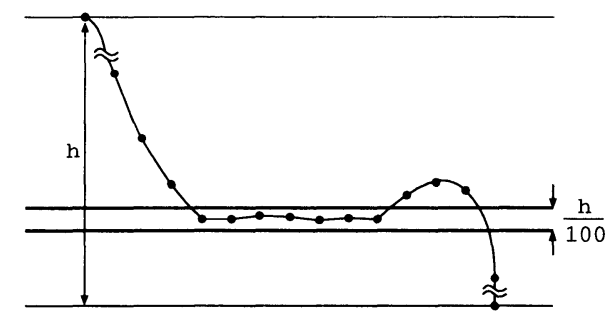

図 3: 直線検出幅の設定

角度デー夕はスプライン曲線で補間されるため、直 線と判断される部分の両端点から 2 点ずつを取るこ とにより直線部分を再現することができる（図 4)。 したがって、最低 4 点連続して水平の場合に直線が 検出されたものとする。

水平線が検出された場合には、両端の 2 つずつの 接点を採用する。このとき、直線の両端点のみを採 用した場合にはその間が曲線となり、元の直線は再 現されない（図 4(1)）。したがって、4点の場合には すべての制御点が使われ、5 点以上の場合には端点 から 2 点ずつ採用し、それらの間の節点は全て削除 する(図 4(2))。

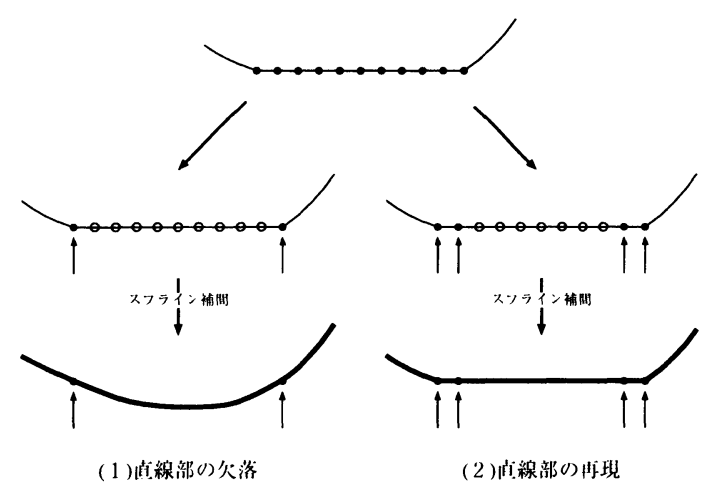

図 4: 直線部分の生成

上記の直線抽出によって検出された部分以外では 全て曲線として処理を行なえばよい。

\section{3 三軸の角度データへの適用}

モーションキャプチャシステムから得られるデー 夕は 3 次元データであり、各フレームごとに 3 つの 軸方向の角度変化がデータとして得られている。し たがって、それぞれの軸のデータに対して制御点削 除を行ない、それぞれの軸の角度情報が壊れないよ うに有効なフレームを選ぶ必要がある。そこでまず、 3 軸それぞれについて制御点削除後の制御点のフレー ム番号を求め、各々のフレームについて、1 軸でも 有効な場合には、そのフレームが有効となるように する。

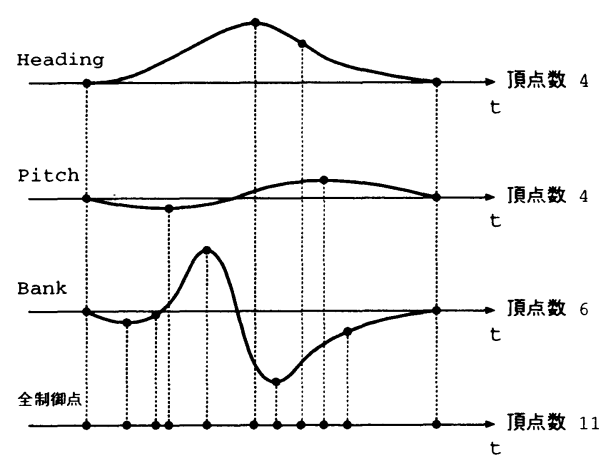

図 5: 三軸の再現に必要な制御点

ここで、さらにデータを削減するために、隣接し たフレームデータのうち削除できるものを検討する。 フレームデータのうち、いずれかの軸データにおい て、極大・極小值をとる点および直線部分の端点は 必ず採択する。また、角度変化が特に大きな部分は、 その部分を再現するためにその両端を含んだ 3 点を 採択する。大きいと判断する基準は、振幅変化の最 大幅の $1 / 2$ を越えるものとした。それ以外の点は、 左右両方のフレームが採択される場合には削除を行 なう（図 7)。

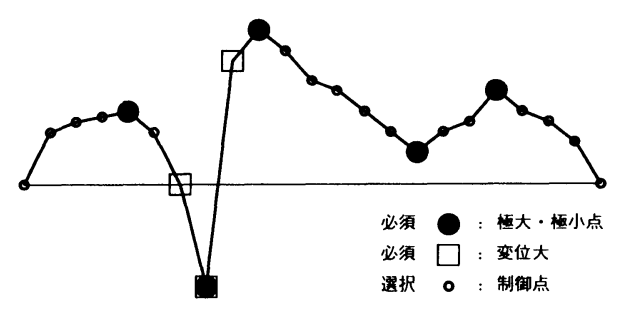

図 6: 採択必須点 


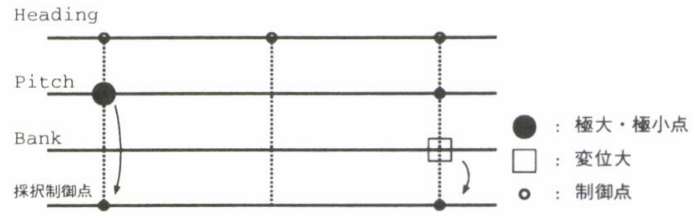

図 7: 不採択点
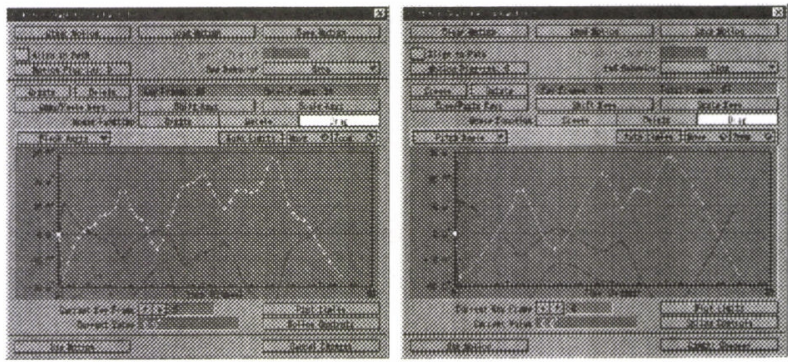

図 9: 制御点削減：Pitch（ $\mathrm{x}$ 軸の回転角度）

\section{4 作画実験と評価}

本論文で提案する手法によりデー夕削減を行ない、 そのデータを用いて動作生成を行なった例を以下に示 す。用いたデータは人体を 18 部位に分け、モーショ ンキャプチャシステムにより得たものである。

削減した結果の動作データを図 8、図 9、図 10に示 す。それぞれ左図は削減前のデータで、右図が削減 後のデータである。元のキーフレーム数は 55 点で、 図 8はy 軸に関する回転角度データでありキーフレー ムは 17 点に削減され、図 9 は $\mathrm{x}$ 軸に関する回転角度 データでありキーフレームは 13 点に削減され、図 10 は $\mathrm{z}$ 軸に関する回転角度データでありキーフレーム は 20 点に削減された。図 11 は提案手法を用いて作 成した両手突きの動作である。元となるデータのフ レーム数は 50 であり、元のデータと比較しても、ほ ほ同様の動作が得られることが確認できた。映像は 左から右、上から下に流れる。
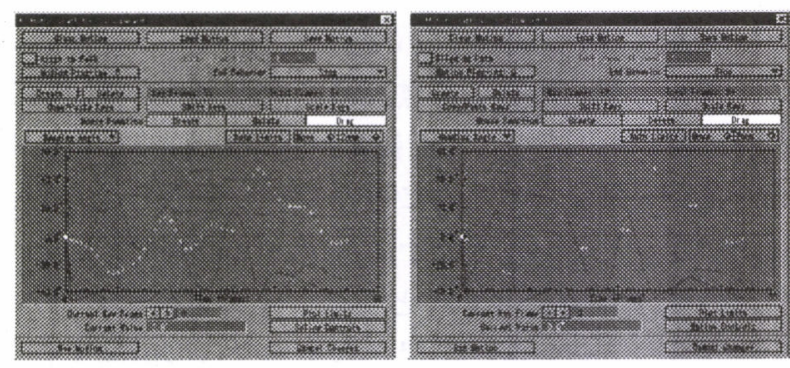

図 8: 制御点削減: Heading（y 軸の回転角度）
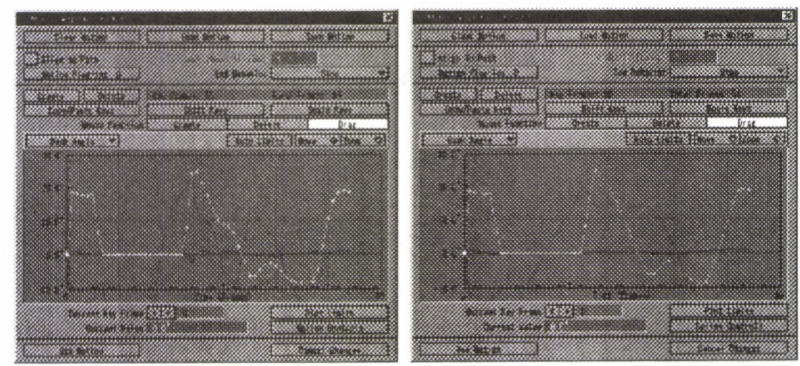

図 10: 制御点削減：Bank（ $\mathrm{z}$ 軸の回転角度）

表 1 には、提案手法によって得られたデー夕を示 している。表は左の列から、

部位

体の部位

\section{H/P / B}

Heading / Pitch / Bank を意味し、それぞれの 軸方向の角度を表す

\section{Mod/All}

隣接制御点削除による制御点数 / 全制御点採択 による制御点数

\section{圧縮比}

フレーム数に対する削除後の比率

となっており、それぞれの部位ごとに処理を行なっ た様子を示している。

表 1の結果から、

- 隣接制御点削除により全制御点採択よりも平均 $8 \%$ 削減された

・提案手法により全フレームの平均 $53 \%$ が削減さ れた 

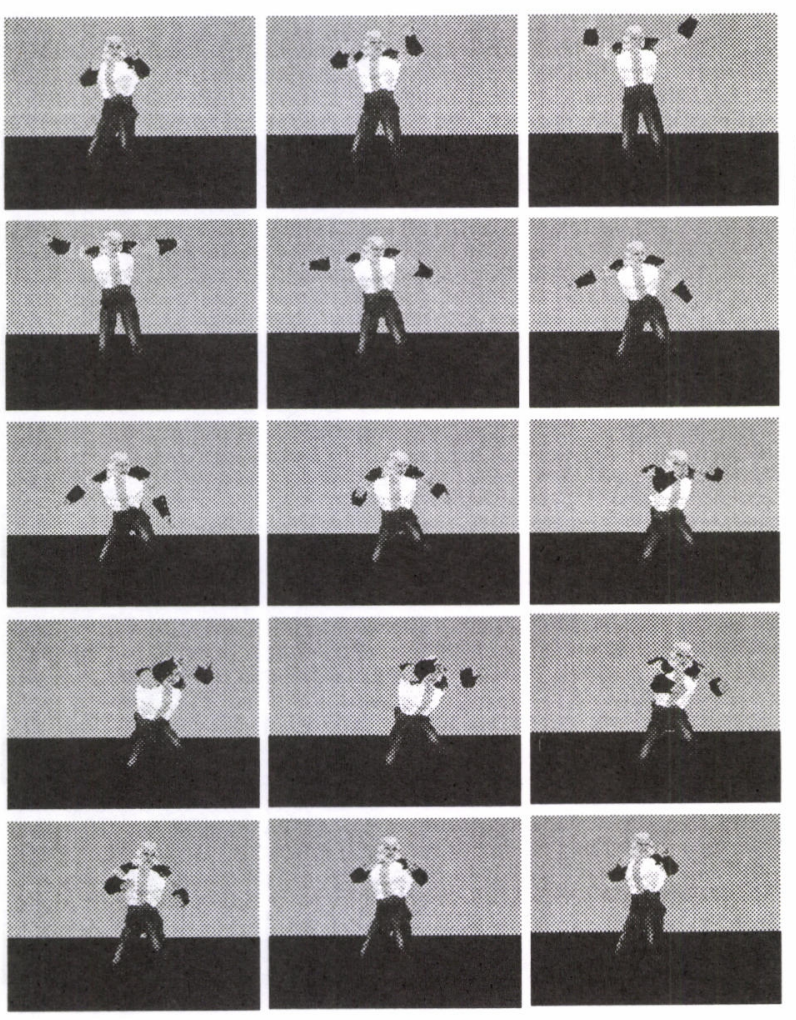

図 11: 制御点削減例

という結果が得られた。

同様に、19 種類の動作に対して、制御点削減を行 なった結果、約 $50 \%$ のデー夕が削減されることが、 実験により確認できた。

\section{4 応用例}

本節では、提案手法を用いて制御点削減を行なっ たデータを用いて、強調表現に利用した例を示す。強 調手法は、関節の角度を強調する角度強調法と、才 ブジェクトを拡大縮小する形状強調法の 2 種類を用 いた $[8]$ 。角度強調法を用いた動作デー夕を図 12 (左 図は制御点削減後のデータで、右図は角度強調後の 角度データとなる)、形状強調を用いた動作デー夕を 図 13 (左図は削減後のスケールが常に 1 のデータで、 右図は形状強調後にスケールが変化した動作データ) に示す。図14は提案手法を用いて制御点削減を行な い、形状強調を加えた連続パンチの動作である。元 のデータと比較すると、動きに合わせてオブジェク トが拡大縮小されていることが確認できた。

本研究では、19 種類の動作に対し実験を行なった
表 1: 制御点削除例（50 フレーム） H:heading, P:pitch, B:bank

\begin{tabular}{|l|c|c|c|}
\hline 部位 & $\mathrm{H} / \mathrm{P} / \mathrm{B}$ & Mod/All & 圧縮比 \\
\hline \hline 尻 & $13 / 6 / 9$ & $20 / 21$ & 0.40 \\
\hline 胸 & $19 / 8 / 13$ & $24 / 28$ & 0.48 \\
\hline 首 & $9 / 13 / 10$ & $18 / 18$ & 0.36 \\
\hline 頭 & $8 / 20 / 13$ & $23 / 25$ & 0.46 \\
\hline 右肩 & $15 / 12 / 10$ & $23 / 26$ & 0.46 \\
\hline 右上腕 & $8 / 12 / 13$ & $21 / 22$ & 0.42 \\
\hline 右腕 & $17 / 8 / 20$ & $24 / 25$ & 0.48 \\
\hline 右手 & $8 / 8 / 8$ & $8 / 8$ & 0.33 \\
\hline 左肩 & $16 / 20 / 11$ & $31 / 32$ & 0.62 \\
\hline 左上腕 & $13 / 10 / 18$ & $28 / 29$ & 0.56 \\
\hline 左腕 & $15 / 10 / 14$ & $23 / 24$ & 0.46 \\
\hline 左手 & $8 / 8 / 8$ & $8 / 8$ & 0.33 \\
\hline 右腿 & $25 / 11 / 15$ & $31 / 37$ & 0.62 \\
\hline 右ふくらはぎ & $11 / 16 / 14$ & $23 / 26$ & 0.46 \\
\hline 右足 & $26 / 13 / 15$ & $31 / 32$ & 0.62 \\
\hline 左腿 & $15 / 14 / 16$ & $26 / 30$ & 0.52 \\
\hline 左ふくはぎ & $8 / 16 / 14$ & $21 / 25$ & 0.42 \\
\hline 左足 & $19 / 10 / 18$ & $27 / 30$ & 0.54 \\
\hline \hline 平均 & $14.1 / 11.9 / 13.3$ & $22.8 / 24.8$ & 0.47 \\
\hline
\end{tabular}

結果、削減されたデー夕は動作強調に対して有効で あることが確認された。
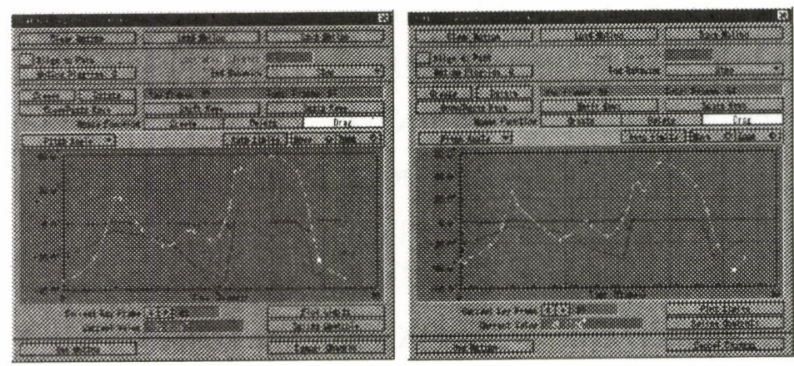

図 12: 角度による動作強調

\section{5 まとめ}

本論文では、㐖長な情報を持つモーションキャプ チャデータから特徵となるキーフレームを抽出し、 デー夕削減を行なう手法について提案を行なった。 本手法により（1）測定した動きの特徵を生かした削 減が可能、(2) 削減の割合をユーザがコントロール 可能、(3) デー夕量の削隇が実現できるので大量の 動きのデータベース構築に有効、（4）デー夕量を削 減することによって、動きの修正が容易に可能、と 

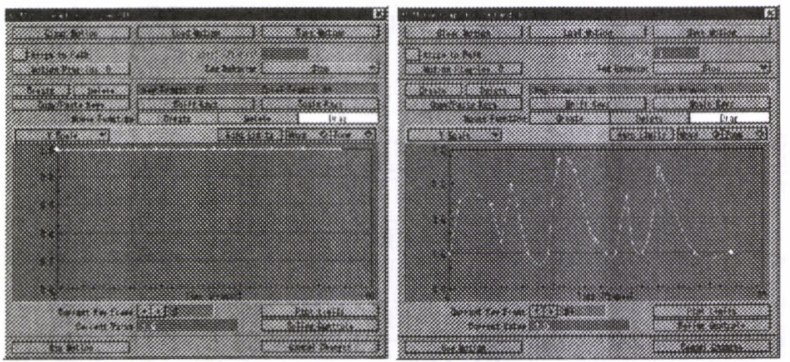

図 13: 形状による動作強調

いう効果が得られ、元の動きの特徵を保持しながら デー夕量は、元の $50 \%$ 以下に抑えることが可能と なった。

また、本手法によって得られたデー夕を動作の強 調表現手法を用いて自動的に強調表現された動作の 生成を行なうことが可能となることを示した。

\section{参考文献}

[1] Harold Whitaker、John Halas、"アニメーショ ンのタイミング技法”、ダヴィッド社、(1983)

[2] 金子満、宮井あゆみ、“テレビアニメを作るーア ニメーション制作工程-”、画像情報振興基金設 立準備委員会、(1990)

[3] Jessica K. Hodgins, Nancy S. Pollard, "Adapting Simulated Behaviors For New Characters", SIGGRAPH97 Computer Graphics Proceedings pp153-162 (1997)

[4] Munetoshi Unuma, Ken Anjyo, Ryozo Takeu chi, "Fourier Principles for Emotion-based Human Figure Animation", SIGGRAPH95 Computer Graphics Proceedings pp91-96 (1995)

[5] 技術系 C G 標準テキストブック編集委員会、“ コンピュータグラフィックス”、C G-AR T S 協 会、(1995)

[6] 佐藤修一、近藤邦雄、佐藤 尚、島田静雄、金 子 満、“アニメーション制作における動作強調 のための Motion Filter"、テレビジョン学会誌 Vol.49, No.10, pp.1280-1287、(1995)

[7] 小林光弘, 近藤邦雄, 佐藤尚, “動作強調のための 角度制御によるMotion Filter”, 情報処理学会 第 56 回全国大会講演論文集 (分冊 4)pp235-236 (1998)
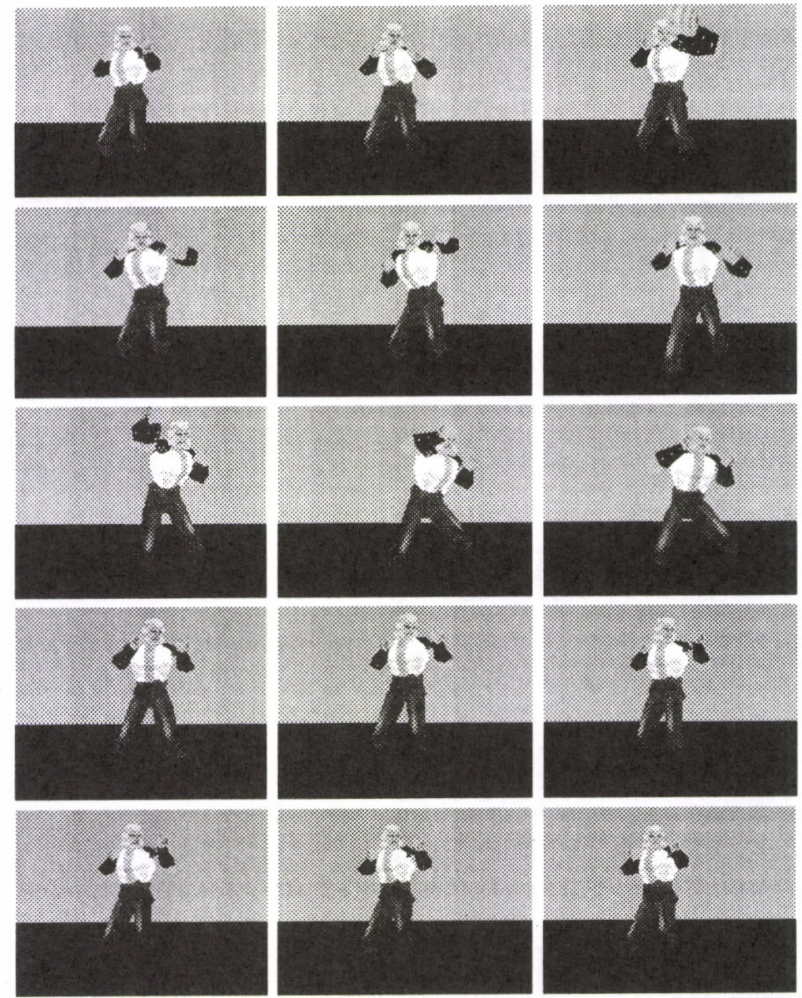

図 14: 形状による動作強調例

[8] 小林光弘, 近藤邦雄 “コンピュータアニメーショ ンのための動作強調手法”, 情報処理学会研究報 告 98- CG -93 pp1-5 (1998)

[9] Mitsuhiro Kobayashi, Kunio Kondo, Hisashi Sato, "Emphasized Expressions Using Motion Filter in Creating Animation", Proceeding of the 8th ICECGDG Conference Vol.2 pp451454 (1998) 